\title{
RACIAL PASSING IN TONI MORRISON'S NOVELGOD HELP THE CHILD
}

\author{
Gol Man Gurung, PhD*
}

\begin{abstract}
This paper examines the racial passing in Toni Morrison's God Help the Child. The core concern of this paper is to observe the stories of five characters who turn to be narrator themselves. Their stories revolve around the process of veiling and unveiling their racial identity. Sweetness herself is a daughter of black parents but she considers herself as white because she got lighter skin which gives her confidence to reject her own daughter, Bride who is very black including these kinds of stories regarding racial minority and color as a sense of insecurity. Morrison gives pictorial view of the modern American society. This shows that race is not a fixed category and the people of one race can behave and perform like the people of another race and pose as who actually are not. Blacks may pass as White and White may pass as Blacks and it shows that one can pass as White even though she is Black. It challenges the fixity of race as a category and reveals its fluidity.
\end{abstract}

Keywords: Colorism, Racial passing, Materialism, Commodification

\section{Introduction}

The novel depicts the history of black suffering caused by the racial bias. Passing is a term in which person carries a false identity to gain a social membership in society without entitlement. Black had to hide their identity because it became a matter of having self-humiliation. The African people faced many problems like domination, sexual abuse and prostitution. Black color became the main cause of suffering for the black people. Almost always the white has been in the position of superiority and the African-American people in a situation of inferiority. AfricanAmerican are largely the descendent of the slaves who were brought from their African homeland by force to work in the new world. Enslaved blacks were forced to work in the clearings and farmland of the new world. They were treated as animals and sold like animals. Their voice was suppressed and they were unable to make their right choices. They were long denied the rightful share in the economic, social and political progress of the United States. Nevertheless, African Americans have made basic and lasting contribution to American history and culture.

God Help the Child as an African American novel that depicts the black suffering caused by the institutional racism and self-humiliation. In this novel, the protagonist named Bride's childhood is very miserable as she didn't get love from her mother who is light skinned because Bride is midnight black and nobody in her family is black. She even becomes seed of her parent's spilt life because her father abandons her and her mother simply because she is born black and he never touches his own daughter. He thinks that his daughter is Sudanese Black. The protagonist, Bride

* Associate Professor of Saraswati Multiple Campus (Humanities Faculty, English Department), Tribhuvan University, Nepal 
who has blue black skin is neglected by white skinned parents who are ashamed of her. Her mother threatens Bride not to call her mother but Sweetness. This shapes the racial domination of the child in an early age being black skinned due to perception that only the white is symbol of beauty. Her childhood is very miserable and she struggles hard in society where no one heals her wounds. Again she has got pain from her boyfriend Booker who calls that she is not a woman he wants; these words hurt her very much. She is abandoned in every aspects of her life. After her boyfriend Booker abandons her, psychologically split Bride heads to North Carolina to find him who lives there with his aunt Queen Olive.

\section{Literature Review}

Morrison's God Help the Child has sustained innumerable interpretative appreciations as long as its announcement in 2015. Roxana Gay writes in The Guardian about Morrison and her novel in relation to the child who is tortured by her parents who do not want to reveal Bride as their daughter. Sweetness tries to save herself in the society by ignoring her own child whose complexion is ebony black. Bride grew up without love and affection. Her childhood was greatly deprived of her parents love. She was immensely tortured by the behavior of her mother Sweetness. Gay writes further:

Bride grew up without love, tenderness, affection or apology. Sweetness makes it clear she saw herself protecting her child from a world that would be even more inclined for her darkness of her skin ... "Some of you probably think it's a bad thing to group ourselves according to skin, color, the lighter, the btter in social club, neighborhood, churches, sororities, even colored schools. But how else can we hold onto a little dignity?" (3)

The novel depicts the troublesome condition of neglected and dispised girl just because of the skin color. She does not get love and affection from her parents. Mother Sweetness is pouring her inner realities living in White community. It is not her choice to deny her daughter but to keep or maintain status in white society; she was forced to deny her child named Bride.

Similarly, Kara Walker in The New York Times reviews that rotation of life Lula and Bridewell. She drops "Lulla," "Ann" and "Bride" from her name to be recognized as Bride by herself. Empowerment and motivation, such person succeed at regional manager in a company leading fascinating life in her early 20s. To make herself dependent and to make her distinct identity she overcomes many obstacles and recognized by her name Bride who always wears white clothes to fascinate people towards her. Walker argues that "at the heart of the novel is a woman, who calls herself bride. Young beautiful with the deep blue black skin and career in a cosmetic company" (11). She is the same who has been rejected "by her light skinned mother, Sweetness who has been poisoned by that strain of color and class anxiety still present in Black community" (42). Sweetness reflects upon her birth: "It did not more than an hour after they pulled her out from between my legs to realize something was wrong" as she was so black that she even scared her mother. (3)

God Help the Child is a novel that investigates the torture faced by the protagonist by her own parents only because she born different than her parents. Her mother Sweetness tells that being black skin color of Bride is not her fault. But her husband Louis think that Sweetness cheats upon 
him and hiding the reality. Then after without any trust upon his wife he left both of them. Sweetness also treated her daughter as the other. She doesn't give her love and affection.

Likewise Mecca Jamilah Sullivan reviewed Morrison's novel as American people's deep rooted psychology in racism and its terror in the characters who want to escape from such bad practices. In order to uplift their status Morrison tries to give voices to the voiceless characters through her novels.

God Help the Child takes up the classical Morrisonean theme: beauty, violence, racism, American blackness and its ghost of personal and communal trauma, the consumption of bodies' - and black women's body in particular - the lasting injury of rejection, exquisite glory of desire. The novel tells the story of Bride, born Lulla Ann Bridewell, a young dark skinned black women whose life has been shaped by her body's failure to meet the norms of consumable womanhood. As a "blue black" child she is rejected by "high yellow" mother Sweetness, who refuses to touch for most of her girlhood . . . Bride's father too vanishes without touching her. (13-4)

Morrison's novel carried the different themes of beauty, violence, racism and so on. Black body is taken as a rejection from the members of American society. Black color is taken as a curse by the people. Parents and child relation is amazing in this novel. Louis, father of Bride blames her for sexual infidelity.

In Blurring The Color Line Richard Alba talks about the racial passing. It is amatter of crossing between the white and black race in the past. Gradually the symptoms of the crossing appear generation to generation. It is very ambiguous innature. One can find different characteristics regarding the race. Richard Alba defines passing as the "extreme case of assimilation" (228). In such situation, Alba explains further, "assimilation in general requires a jettisoning of membership in one group and assumption of the risks involved in trying to gain acceptance in another. The risk in passing one exceptionally high because of the need to conceal one's origin perhaps even from those closet to one-self" (228).

\section{Theory and Textual Analysis}

Passing is a double-dealing that permit a person to adopt certain roles or identities from which he would be prohibited by overcoming social standards in the absence of his confusing conduct. The classic racial passer in the United States has been the White Negro the individual whose physical appearance allows him to present himself as white but whose lack of lineage makes him a Negro according to dominant racial rules.

Richard Alba's notion of racial passing can be shown in the Morrison's God Help the Child. As Alba portrays that the passing became the main ambiguous term that the character in Blurring the Line. Similar kind of ambiguity and confusionappears in the character. In the novel white coloured woman gave birth to the black baby. At that moment she was showing her innocence by saying that it is not her fault to give a birth to the black child. Sometime due to passing some people take the advantages by keeping their standard high as the white people. As the time passes there came unbelievable appearance to the people. When a person passes a white he takes equal 
rights from the authority. But the birth of black child becomes a matter of problem for such passers.

God Help the Child presents the very different reality of African American people. They have very complicated life where they cannot remain confident in their own identity. They spend their whole life in a terror and horror from generation to generation. Their identity is not fixed and they cannot fully claim who they actually are. Sweetness, through her monologue, is expressing her views by declaring many events which are the matters of self-humiliation. She knows about the originality of her passing. To maintain a social status of white, she is pretending to be white. But when her daughter Bride was born with black colour, she is sharing the different events of the people. She even does not breastfeed her daughter. She says that nursing to her child was like having a black child sucking her nipple. So she bottle feeds rather than breast feeding to her child.

Gayle Wald in her book Crossing the Line has analysed works from many well-regarded African American writers and film makers.Gayle's book analyses racial passing, identity and adaptability in the twentieth century. She says that the passing is deep rooted in the mind of people whose generation is gone through the line of passing but they have to face some challenges during their life time. Regarding these issues, Gayle Wald argues:

I have been arguing throughout this study that racial passing, as a social practice, is mediated by the "looking relations of white supremacy. In saying this, I have meant first to suggest that the specific conditions and modalities of racial passing are circumscribed by normative visual epistemologies of race, which assign meaning and value to visualized traits ofhair texture, skin color, and the like. (169)

According to Wald, racial passing is a social practice. To erode race's authority, Wald argues, we must understand how race defines and yet fails to represent identity. She uses cultural narratives of passing to illustrate both the contradictions of race and the deployment of such contradictions for a variety of needs, interests and desires.

Allyson Hobbs in biography A Chosen Exile: A History of Racial Passing in American Life presents the things related to racism where people want to pass. In her biography she has presented that many African Americans passed as white. Centuries ago African American people were enslaved in the house of white masters. Enslaved women were raped by the masters and from the African American women babies were born white and they declare themselves as a people of white community. Gradually those who were born mixed blood gave birth to a mysterious child. Sometime a baby is born white and sometime black. It shows racial passing in the African American People. Hobbs says that "Racial passing is an exile, sometimes chosen, sometimes not"(4). It means that through the racial passing people are able to take advantage from the society but sometime they lack to take the advantages because of the ambiguous appearance of the African American people. Hobbs furthermore adds that "Racial passing in the American context must be acknowledged as a subset of a much larger phenomenon that encompasses multiple disguises and forms of dissemblance" (32). As time passes, different complexion of babies is born from the white people because inwardly they carry the Negro blood in their veins since the time of being slave of white master. Hobbs again adds that:

Passing is a continuous and enduring historical phenomenon that opens a wide window onto larger issues about inconstant racial definitions, the changing dynamics of race 
relations, and the complex and circuitous routes along which African American identity has developed in the United States. First, racially ambiguous men and women passed as free in the fluid, bustling, and multiracial world of the eighteenth century mid- Atlantic, where opportunities for self- fashioning abounded and where not all blacks were enslaved and not all whites were free. (25)

According to Hobbs, passing is continuous and historical process which is never ending. This is ongoing process. In multiracial world, due to passing, the appearances of people appear in an ambiguous way in the society. He does not believe that all the blacks are enslaved and all whites were free.

While applying Hobbs theory in the Morrison's God Help the Child we came to know that passing is a never ending process. White couple's child Bride was born black because of the multiracial community, where one's identity is not certain but its fluidity. Sweetness and her husband belong to white but their daughter belongs to black. Explicitly such event made people shocked but implicitly it is because of racial passing. In white society it is very difficult to create an identity by black people but there in the Morrison's novel. Bride was able to create her own identity as a regional manager in Cosmetic Company Sylvia Inc. In order to make her distinct identity in white society, time and again she drops the word from her name and lastly she identifies herself with the name Bride.

Bride expresses her inner activities how she accuses innocent Sofia Huxley and how she was treated by her parent and all the people who went in support of Bride. Sofia Huxley was a primary teacher who is black. She is accused of child molestation. When Bride points at Sofia in the court, she was amazed how the little girl dared to accused. At that moment she was not able to go beyond the accusation. This shows that even the educated school teacher's voice was repressed and she was unable to utter a single word from her mouth it shows that how American society is engulfed by the racial discrimination. Huxley who belongs to black community is accused by the Bride. It is intra-racial conflict where same race deceived the person of same race. All the people who were in court play a role of stimulator to the Bride. Huxley's social prestige was lowered because of false blame toward her. After accusing Sofia Huxley she was greatly thanked by the people who surround her. When Bride glanced to her mother she was amazed because Sweetness smiled with mouth and eyes that she had never seen before. Even her father gave her thumb-up. Bride says that the best expression she saw in the face of her mother Sweetness. As they walked the court house her mother held her hand that she never got such tender touch from her mother before. Bride says that it surprised her as much as it pleased her because she always knew she didn't touching her.

The major part of the novel God Help the Child sets in California. It is a developed city where people do not care about other and they just remain self-centred towards their activities. Every human relation is based on money mongering psychology. People like to gain name and fame by struggling hard in the society. Morrison mocks at the psychology of character which is designed by the materialistic society. When Bride gets successful in her career as the manager of cosmetic company, she went to visit her primary school teacher whom she accused for child molestation. Sofia Huxley spends fifteen years of long imprisoned life in pitiful way. After her release from prison, Bride went to meet her to compensate her by providing money. At that moment Huxley says, "I didn't know what she was talking about or what she wanted until she threw money at me. 
She was one of the students who testified against me, one of the ones who helped kill me, take my life away. How could she think cash would erase fifteen years of life as death?" (69-70). By this statement, Morrison critiques the materialistic trend of the American society. Here the psychology of Bride is also polluted by the materialistic norms and values where she thinks that the money can replace her guilt. It is a great satire to the money minded people who think that money is everything to make worse thing better.

Morrison tells the story of many characters who suffered from the materialistic norms and values in the American society. She depicts reality of American culture. Rain appears as a mysterious little white girl in the novel whose story is also important to know the reality that how much the American people psychology is drowned in the materialistic life. One day when Rain was drenched in the rain she was rescued by the kind hearted couple Steve and Evelyn. Even both couple were unknown about the girl, her name, her family. They provide shelter for her. Later on, in her narration she deploys that she is victimized by the materialistic society where the money is given priority. Human feelings and emotions lagged behind in the face of money psychology. Furthermore, she explains that she wants to "chop her head off" (102). It means that she wants to cut her mother's head if she finds her now. Moreover she expresses her anger towards her mother because her mother forced her to involve in prostitution for making money. Her mother took the money from the sex-driven customers after her daughter's prostitution. One day when Rain misbehaves to one of the customers of her mother; she is chased away from the house. In this regard Morrison speaks through the words of Rain, "Some guy. A regular. One of the ones she let do it to me.. . He stuck his pee thing in my mouth and I bit it. So she apologized to him, gave back his twenty-dollar bill and made me stand outside... She wouldn't let me back in. I kept pounding on the door. She opened it once to throw me my sweater." (101-02). Throughout this circumstances Morrison makes fun of money mongering psychology of American people who in the name of money can cross the limitation of human values. Human values are commodified on the basis of skin color in American white society.

Steven J. Belluscio, Professer of English at Borough of Manhattan College/CUNY, is the author of To Be Suddenly White. It focuses on the theme of passing. Passing means that Negro becomes a white man and he takes the position of higher caste. Passing is viewed by the scholars as black/white racial binary. Critics take racial binary as a literary realism. Belluscio views that "In the racial passing narrative, a character attempts (successfully or not) to shed all overt evidence of racial difference and imperceptibly enter mainstream society"(26). While applying the Belluscio's theory in the Morrison's novel too, we know that the protagonist named Bride was also the subject matter of racial passing. She was unnoticed by the people and to lure the person or to make attention of people toward her Bride accuses her primary teacher Sofia Huxley for a child molestation though her guilty. It is all done by the Bride to bring her in the position for entering in the mainstream.

Belluscio in To Be Suddenly White explores the troubled relationship between literary passing and literary realism. Drawing the ideas from Gayle Wald, Belluscio further adds that:

The durability of the black/white paradigm may in certain cases be abetted rather than undermined by its instability, in so far as this quality lends it a discursive mobility and flexibility . . . it examines not only black-to white but also white-to-black racial passing 
and in that it reads these phenomena in not only literature but also in musical culture, film, and confessional narrative. (32)

Belluscio in his creative work To Be Suddenly White brought the idea of Wald's Crossing the Line. In the Crossing the Line there is there is portrayal of the racial passing in Twentieth century. It examines not only black-to-white but also white to black racial passing. It does not only deals with the literature but also deals with the musical culture, film and confessional narrative. In god Help the Childthere we can see that not only black -to white passing is mentioned but also white to black racial passing occurs. Bride's parents pass as white but their daughter passes black.

Bride's mother Sweetness makes her daughter deprived of love and affection. She does not want reveal that in her blood there is Negro blood running in her vein. She says that she was not a bad mother. The reason behind doing some hurtful things is to protect her child. She says that "I wasn't a bad mother, you have to know that, but I may have done some 'hurtful things to my only child because I had to protect her. Had to all because of skin privileges. At first I couldn't see past all that black to know who she was and just plain love her. But I do. I really do. I think she understands now. I think so" (43). Sweetness says that she treated her child badly because to protect her. She thinks that due to skin privileges in the society she treated her child in a wrong manner. She says that in past those who passed as black does not want to reveal their past in order protect them from racially engulfed society.

Bride feels a kind of racial domination through the behaviour of her mother. She overcomes many difficulties in her life. Sweetness in order to hide her real identity from the racially dominated society she does not wants to attend the parent teacher meetings or volleyball games. Bride portrays that her neighbours and their daughter agreed in the rude behaviour of her mother to Bride:

She's sort of pretty under all that black. Neighbours and their daughters agreed. Sweetness never attended parent-teacher meetings or volleyball games. Iwas encouraged to take business courses not the college track, community college instead of four- years state universities. I didn't do any of that. After I don't know how many refusals, I finally got a job working stock never sales where customers would see me. I wanted the cosmetics counter but didn't dare askfor it. (35-36)

Sweetness does not want to recognize as a mother of Bride because of fear of white society where African Americans rights were limited and they are lowered by the people who are in power. Bride was not encouraged to join in college rather she was encouraged to take business courses. She was supported for community college instead of four- year's state universities. But Bride did not go in the track of her mother. After facing many refusals at many job she finally got work in the working stocks. In working stocks she never sells where customers could see her. She has a kind of humiliation from her inner feeling. Bride was not satisfied with her work in working stocks but she wanted a cosmetics counter but of fear of her mother she cannot dare to express her feeling.

When Bride went for her interview at a cosmetic company (Sylvia Inc) her designer of dress suggests her "You should always wear white Bride. Only white all white all the time" (33). Bride is encouraged to wear white dress. Her blackness is commodified. It is self pride for black and no need to pass anymore in the society. White dress increases blackness of her skin. They use her 
blackness as a marketing strategy. It is not whole hearted acceptance of black. Bride attended the party where she was complimented by the people. Here, the people acknowledge that black is also beautiful. This is the mark that people are coming out of the racial beauty. I am complimented constantly at the party- how beautiful, how pretty, so hot, so lovely,everyone says, but no one questions the absence of earrings" (51). In the party Bride was praised immensely by the people but herself feels a lack of her earrings. From her view we can guess that she humiliates herself. Her psychology is guided by materialistic ideology that only the person who wears ear rings are only belong tostandard people. Bride lowered her self- esteem. So, while getting appreciation from the people in the party she said that nobody ask her for absence of earrings.

An American literary critic Henry Louis Gates in the Signifying Monkey explores the relationship between black vernacular tradition and African American tradition. It is a theory of African American Literature. The black traditionis double-voiced. In this literary criticism through the slave narratives he makes the white written text speak with a black voice. Regarding the issue of passing Gates says that:

Nevertheless, the two figures are related as functional equivalents because each in its own way stands as a moment of consciousness of black of language use, of rhetorical structures and their appropriate modes or interpretation.. how and why formal literary language departs from ordinary language use. The metaphor of a double-voiced Esu Elegbara corresponds tothe double-voiced nature of the signifying(s) utterance. When one text signifies upon another text, by topological revision or repetition and difference, the double-voiced utterance allows us to chart discrete formal relationships in AfroAmerican literary history. (88)

According to the Gates due to racial passing African American tradition is doubled voiced. To bring the African American in the mainstream he prioritizes the African American tradition. The Signifying Monkey expands the arguments of figures in Black makes a significant contribution to literary theory, African-American literature, folklore, and literary history. Similarly, Morrison in her novel God Help the Child through the protagonist Bride and other characters in the novel she gives voices to them.

Gradually there is emergence of the concept Black is beautiful. Sweetness regrets on inhuman behaviour to her daughter Bride. She time and again remembers time of 1990s when there was a massive racism in the society. Bride was also born at that period where she is deprived of love from her parents. Sweetness could not love her daughter honestly simply because of discriminatory social belief of the time. She has also changed into a better human being by the end of her time. Sweetness says that "The last time I saw her she looked so good, I forgot about her colour" (177). It means that the racism is not innate rather it is social construction or mindset of people. Is a proof that Sweetness has a pride in her black color. Sweetness realizes her guilt and says: "If I sound irritable, ungrateful, part it is because underneath is regret. All the little things I didn't do or did wrong. I remember when she had her first period and how I reacted. Or the times I shouted when stumbled or dropped something. True was really upset, even repelled by her skin when she was born" (177). This is the mark that Sweetness realizes her ill treatment towards her daughter. She is very regretful at the present. The flow of time changes the psychology of a people. It is a meaningful transformation which provides a positive thought for all the people. 


\section{Conclusion}

Toni Morrison, through her novel, depicts the theme of racial passing. Passing theory describes distinct process in which the people identify them as wrong identity. Similarly, in the novel Sweetness communicates herself as a white community. She does not want to reveal herself that her past generation gone through in the process to passing. The novel opens with the monologue of Sweetness where she remembers that her own mother Lula Mae has passed easy. Sweetness recollects the moment of her mother's talk. When her mother and father went to court house for marriage there were two Bibles and they had to put their hands one reserved for Negroes and other for white people. She recalls all her memory because when her daughter was born with black skin to console herself she does so. Sweetness treated Bride as not her child. She does not take her daughter with her in the society. Even she told Bride not to call mother rather Sweetness.

\section{Works Cited}

Alba, Richard. Blurring the Color Line: The New Chance for a More Integrated America Press, 2009.

Belluscio, Stephen J. To Be Suddenly White: Literary Realism and Racial Passing. University of Missouri, 2006.

Elkin, Susan. "The Tyranny of Memory can Make a Destructive Adversary."The Independent Daily, 18 April 2015. https://www.independent.co.uk/artsentertainment/books/ reviews/god-help-the-child-by-toni-morrison-book review-the-tyranny-of-memory-can-make-a-destructive-10182633.html

Gates, Henry Louis Jr. The Signifying Monkey: A Theory of African-American Literary Criticism. OUP, 1998.

Gay, Roxane. "Incredibly Powerful." The Guardian, 29 April2015.https:/www.theguardian.com/ books/2015/apr/29/god-help-the-child-toni-morrison-review-novel.

Hobbs, Allyson. A Chosen Exile: A History of Racial Passing in American Life. Harvard UP,2014.

Sullivan, Mecca Jamilah. "Color Politics Remix Reviewed Work(s): God Help theChild by Morrison."The Women's w of Review Books, vol. 32, no. 6, 2015.

Gtald, Gayle. Crossing the Line: Racial Passing in Twentieth -Century U.S Literatureand Culture. Duke University Press, 2000.

Walker, Kara. "Toni Morrison's God Help the Child." New York Times, 13 April, 2015, pp. 11-12. 